\title{
Sosyal Medya Risklerinin Yönetilmesinde İç Denetimin Rolü*
}

\author{
Erdi KAYA** \\ Banu Tarhan MENGI' $\dot{I}^{* * *}$
}

\section{$\ddot{O Z Z E T}$}

Sosyal medya, teknolojik gelişmelerle birlikte giderek gelişen dijital dünyaya ayak uydurmaya çalışan ve yenilikleri yakından takip etmek isteyen kurumlar için çok önemlidir. Hızı ve genişs etki alanı sayesinde kurumlara sayısız katma değer sağlayan sosyal medya, kurumların önemli bir parçası konumundadır. Her geçen gün yeni bir işlevi keşfedilen sosyal medyanın kurumlar için önemi giderek artmaktadır. Ancak sosyal medya yapısal özelliklerinden dolayı önemli riskler barındırmaktadır. Sosyal medya riskleri doğru bir şekilde yönetilmediği takdirde kurumlar açısından ciddi bir tehlike arz etmektedir. Kurumlar için önemli bir tehdit unsuru olan sosyal medya risklerinin yönetilmesi hususunda, iç denetimin önemli sorumlulukları bulunmaktadır. Bu çalışmada sosyal medya konusunda iç denetimin üstlendiği sorumluluklar anlatılmaktadır.

Anahtar Kelimeler: Sosyal Medya, İ̧ Denetim, Sosyal Medya Riski

JEL Sinıflandırması: M40, M42.

\section{The Role of Internal Audit in Managing Social Media Risks}

\section{ABSTRACT}

Social media is very important for organizations that are trying to keep pace with the digital world that is developing together with technological developments and wants to follow trends closely. Social media is an important part of the organizations, providing countless added value to corporations through its speed and wide range of influence. The social media, of which a new function is being dicovered each passing day, is becoming increasingly important for businesses. However, there are significant risks due to the structural characteristics of social media. Social media is a serious threat to the organization if it is not managed properly. Internal audit has important responsibilities in managing social media risks that are a significant threat to corporations. The responsibilites that internal audit has undertaken about social media is explained in this study.

Keywords: Social Media, Internal Audit, Social Media Risk

Jel Classification: M40, M42

\footnotetext{
${ }^{*}$ Bu makale Doç. Dr. Banu Tarhan Mengi’nin danışmanlığında, Erdi Kaya tarafından hazırlanan "Sosyal Medya Risklerinin Yönetilmesinde İç Denetimin Rolü ve Medya Sektöründe Bir Araştırma" başlıklı yüksek lisans tezinden üretilmiştir

** Marmara Üniversitesi, Sosyal Bilimler Enstitüsü, errdikaya@ gmail.com, ORCID ID: 0000-0001-5448-0706

**** Doç.Dr., Marmara Üniversitesi, İşletme Fakültesi, btarhan@marmara.edu.tr, ORCID ID:0000-0002-18038125
} 


\section{GíRiş}

İletişim teknolojilerinde yaşanan gelişmeler sonucu ortaya çıkan sosyal medyanın kurumlar için önemi giderek artmaktadır. Geleneksel medyanın kurumlara sağladığ faydadan daha fazla verim sağlıyor olması ve kurumlar için istenilen sonuçlara daha hızlı ulaşılmasına imkan tanıyor olması, kurumları sosyal medyaya önem verme ve bu alanda faaliyet gösterme durumunda birakmıştır.

Sosyal medya, etkili ve doğru bir biçimde yönetildiğinde, kurumsal hedeflere ulaşılması açısından önemli katkılar sağlamaktadır. Ancak yanlış kullanıldığında, kurumlara çok ciddi zararlar verebilecek risklerin ortaya çıkabilmesine de neden olabilmektedir. Sosyal medyanın yarattığı etki alanının çok geniş olması ve yayılma hızının da yüksek olması nedeniyle sosyal medyanın olumsuz etkileri kurumlar için telafi edilmesi çok zor durumlar ortaya çıkarabilmektedir.

Zaman içerisinde değişen ve gelişen yapısıyla birlikte iç denetim faaliyeti, kurumların hedef ve amaçlara ulaşılmasına yönelik çalışmalar yapmakla kalmayıp, işletmeye değer katmayı da hedeflemektedir. $\mathrm{Bu}$ doğrultuda faaliyet gösteren iç denetim, kuruma zarar verebilecek her türlü riskin gerek önlemesi gerekse yönetilmesi konusunda önemli roller üstlenmektedir.

$\mathrm{Bu}$ doğrultuda çalışmanın amac1; sosyal medya risklerinin yönetilmesinde iç denetimin oynadığı önemli rolün ortaya konulmasıdır.

\section{KURUMLARIN SOSYAL MEDYADA BULUNMA NEDENLERİ}

Sosyal medya devrimi sonrasında giderek önem kazanan kavramlardan biri sosyal işletme kavramıdır. Sosyal işletmeler müşterilerini sanal ortamlar dahilinde değerlendirerek, sosyal insana ulaşmayı ve bu yolda başarı sağlamayı istemektedirler. Bunu sağlamak için bütünleşik iletişim araçlarını etkin kullanabilmek ve bunu sosyal medya ile desteklemek çok büyük önem taşır. Sosyal insanlar ise birçok bilgiye farklı kanallardan erişmekte, yeni haberleri Twitter, Facebook gibi sosyal ağlardan takip etmektedirler. Edindiği bu bilgiler sosyal insana çabuk geribildirimlerde ve yorumlarda bulunma imkanı tanımanın yanı sıra teknolojik gelişmeleri yakından takip etme ve son moda uygulamaları vakit kaybetmeden kullanmaya başlama konusunda yardımcı olur. Bu sebeplerle sosyal insan kurumların sosyal ağlarda yer almasını ve aktif biçimde güncel bilgilerle sürekli ilgi çekecek paylaşımlarda bulunmasını istemekte ve beklemektedir (Vardarlıer, 2016: 45).

Günümüzde sosyal medyayı kullanan tüketicilerin, sosyal medyanın var olmadığ 1 dönemlerdeki tüketicilerden farklı özellikleri bulunmaktadır. Sosyal medya kullanıcıları, öğrendikleri bir bilgiyi veya edindikleri bir tecrübeyi sosyal medyadan paylaşma ve yorumlama eğilimindedirler. $\mathrm{Bu}$ paylaşımlar ve yorumlamalar diğer sosyal medya kullanıcılarının oylamaları ve beğenmeleri sonucunda kısa sürede çok daha fazla kullanıcıya ulaşmaktadır. Sosyal medya kullanıcılarının iyi veya kötü tecrübeleri diğer sosyal medya kullanıcılarının yani kurumların potansiyel müşterilerinin satın alma kararlarını etkilemektedir. Ayrıca kurumlar sosyal medya platformlarında doğrudan hedef kitleleriyle etkileşimde olabilme imkanı bulmaktadırlar. Bu gibi önemli etkileri nedeniyle sosyal medya 
platformlarında var olmak, kurumlar için bir zorunluluk haline gelmektedir (Mavnacıoğlu, 2015: 79).

Sosyal medyanın en etkili kullanım sahası pazarlama, satış ve halkla ilişkiler olmakla beraber satın alma davranışları, müşteri ilişkileri yönetimi, marka yönetimi gibi kavramlarla da yakından ilgilidir (Vardarlıer, 2016: 47). Sosyal medya kurumların güvenilir ve güçlü bir kurum algısı oluşturmasında önemli bir yere sahiptir. Ayrıca olumlu bir marka imajı yaratma ve rekabet avantajı kazandırma bakımından da önemli katkıları bulunmaktadır (Kazancı ve Başgöze, 2015: 441).

Müşterileriyle daha yakından iletişim kurmak isteyen kurumlar için ise sosyal medyanın başka bir anlamı daha bulunmaktadır. Artık kurumların ellerinde, kurumun kendisi ve ürünleri hakkında konuşulanları dinleyebilecekleri ve gerektiğinde müşterilerle doğrudan iletişime geçebilecekleri bir platform bulunmaktadır (Dağıtmaç, 2015: 36).

Geleceğe ait hedefleri olan kurumlar makro trendleri yakından takip ederek çağın gereksinimlerini iyi analiz etmektedirler. Bu bağlamda ele alındığında sosyal medyada yer almak, kurumun hedeflerine ulaşmasında ve kurumsal itibarın sağlanmasında bir araç olarak kullanılmaktadır. Bu yüzden sosyal medyanın etkili bir şekilde kullanılması ve yönetilmesi kuruma değer kazandırmaktadır (www.koc.com.tr, 2017).

\section{SOSYAL MEDYA RISSKLERI}

Sosyal medyanın kontrolü oldukça zordur çünkü sosyal medyanın etki alanı çok geniştir ve sosyal medyadaki paylaşımlar çok hızlı bir şekilde yayılmaktadır (Vardarlıer, 2016: 66). Sosyal medya kullanıcıları sosyal medyada konuşulan konuların içeriğini ve doğruluğunu bir gazeteci gibi araştırmamaktadır. Doğruluğu net olmayan bu paylaşımlardan dolayı sosyal medyada bilgi kirliliği çokça yaşanmaktadır. Bu yüzden kurumların sosyal medyada bir kriz yaşama olasılığı oldukça yüksektir (Çakır, 2016: 50).

\subsection{Sosyal Medya Riski Türleri}

\subsection{1. İtibar Kaybı}

"Kurumsal itibar bir işletmenin geçmiş faaliyetleri ve gelecekteki durumu ile ilgili olarak paydaşların algılamalarıdır (Çakır, 2016: 23)."

İtibar için Robert Bosh’un söylediği “İtibarımı kaybedeceğime servetimi kaybetmeyi tercih ederim.” sözü itibarın ne kadar önemli olduğunu anlatmaktadır. Gününüzde kurumların geleceğe dönük tüm hedefleri sürdürülebilirlik üzerine kurulmuştur. Sürdürülebilirliğin temelinde ise kurumsal itibar bulunmaktadır. Kurum, itibarını zedelerse sürdürülebilir olması imkansız bir hale gelecektir (Sezgin, 2014: 40).

Sosyal medyadaki itibar, kullanıcıların sıklıkla kullandığı sosyal medya platformlarında kurumun adı yazıldığında ortaya çıkan içerik, ifade ve yorumlardan oluşmaktadır. Kurum ile ilgili çeşitli anahtar sözcükler yazıldığında Twitter'da kurumun ürünleri hakkında atılmış tweetler, Facebook'ta paylaşılan yorumlar ya da Youtube üzerinde kurumun ürünlerini test eden kullanıcılar gibi birçok içerik kurumun sosyal medyadaki 
kullanıcılar tarafindan nasıl anıldığını göstermektedir. Sosyal medyada oluşturulan bu içerikler sonucunda kurumun itibarı olumlu ya da olumsuz yönde etkilenmektedir (Çakır, 2015: 45).

\subsubsection{Mali Kayıplar}

Mali kayıp riski, kurumların sosyal medyada karşılaştıkları olumsuzlukların finansal yansımasıdır (Mennie, 2015: 47).

Sosyal medyada kurumlar hakkında yapılan olumsuz yorumlar ve eleştiriler kurumların kendi hatalarından olabileceği gibi kasıtlı bir şekilde çıkartılmış söylentilerden de kaynaklanabilmektedir. Bu iki durum neticesinde de eğer kurum bu durumu engelleyemezse, insanlar kurumun ürünlerini veya hizmetlerini tercih etmekten vazgeçebilmektedir (Cross, 2014: 44).

$\mathrm{Bu}$ tip finansal riskler borsada işlem gören kurumlar için çok daha önemlidir. Kurumun hisse senedi değerinde azalışa sebep olabilmektedir. Daha da vahimi ise bu durumun uzun vadede yatırımcı için güven kaybı yaşanmasına neden olabilmesidir. (Cross, 2014: 44).

\subsubsection{Gizlilik İhlalleri}

Teknolojinin giderek gelişmesiyle birlikte internet ortamında gerçekleşen bilgisayar korsanlığ1 faaliyetleri çok sık yaşanır duruma gelmiştir. Sosyal medyadaki gizlilik ihlalleri; güvenlik açıkları, yazılım ve donanımların yetersiz olmasından kaynaklanmaktadır. Korsan yazılımlarla kurumların veri tabanına girip sosyal medya hesaplarının şifrelerini ele geçiren internet korsanları kurumları zor durumda birakmaktadır. İnternet korsanlarının diğer bir yöntemi sosyal medya hesaplarını yöneten çalışanların aldatılmasına yöneliktir. Bu yöntem sosyal mühendislikle ve kimlik avı sayfalarıyla gerçekleştirilmektedir. $\mathrm{Bu}$ tip bilgisayar korsanı saldırıları kurumların gizliliğine ilişkin sorunlar çıkarmanın yanı sıra itibarının zedelenmesine ve mali kayılara da neden olmaktadır (www.pwc.com.tr, 2017).

Web güvenliği açısından sosyal mühendislik; sosyal medya kullanıcılarına sahte hikayeler anlatarak kendilerine güvenmelerini sağlayarak bilgi edinmeyi amaçlamaktadır. Elde ettikleri bilgilerle kurumların Web güvenliğini aşmayı hedeflemektedirler. İnsanlarla kurulan ilişkiyi istismar etmeye yönelik bu davranışın temelinde sosyal medya hesaplarına ait şifrelerin ele geçirilmesi amaçlanmaktadır (Karahasan, 2017: 16). Diğer bir yöntem ise resmi Web sayfası gibi görünen ama aslında bir "phishing" (kimlik avı) sayfası olan yerde sosyal medya adreslerine giriş yapılmasını isteyen bir e-posta yoluyla gerçekleşmektedir. Buradan yapılacak olan girişle kullanıcıların tüm şifre bilgileri ele geçirilmektedir (Mennie, 2015: 52).

Tüm bu saldırılar sonucunda ele geçirilen sosyal medya hesapları her türlü istismara açık olmaktadır. İnternet korsanları ele geçirdikleri kurumların adreslerinden; kuruma ait gizli bilgilerin paylaşılması, terör örgütlerinin propagandasının yapılması, sahte haberlerle borsa manipülasyonu yapılması, kötü amaçlı yazılımların sosyal medya aracılığıyla daha fazla kullanıcıya yayılması ve kurumla alakalı küçük düşürücü paylaşımlar yapılması gibi birçok zararlı faaliyetlerde bulunabilmektedir (Oxley, 2013:91). 


\subsubsection{Hukuki Riskler}

Kurumlar sosyal medyada yapmış oldukları hatalar neticesinde bazı hukuki riskler ile karşı karşıya kalabilmektedirler. Sosyal medyadaki bu ihlaller çeşitli şekillerde olabilmektedir. İşçi ve işveren arasındaki ilişkilerden dolayı yaşanabilecek hukuki riskler, paylaşılan içerikler ile alakalı telif ve hak ihlalleri, kamu düzenine ve ahlaka uygun olmayan paylaşımlar, reklam ve kampanyalardaki yanlış ve yanıltıcı ifadeler gibi sebeplerle kurumlar hukuki risklerle karşı karşıya kalabilmektedir. Yapılan yargılamalar neticesinde de suçlu bulundukları hallerde önemli maddi cezalara çarptırılabilmektedirler (Akar, 2016: 69).

Sosyal medya, kullanıcıların özgürce görüş, yorum ve paylaşım yapabildiği ve herhangi bir sınırlamanın olmadığı bir platformdur. Sosyal medyada bu denli özgürlüğün bulunması tamamen hukuksuz bir ortam olduğu anlamına gelmemektedir. Sosyal medyadaki tüm kullanıcılar ve kurumlar sosyal medya platformlarından yaptıkları tüm paylaşımlarından dolayı sorumludur (Akar, 2016: 69).

ABD ve Avrupa'da sosyal medya platformlarında gerçekleşen iletişimi düzenleyen hukuk kuralları bulunmaktadır. (Scoot ve Jacka, 2013: 86) Ülkemizde de 2007 yılında yürürlüğe giren 5651 sayılı kanun "İnternet ortamında yapılan yayınlananların düzenlenmesi ve bu yayınlar yoluyla işlenen suçlarla mücadele edilmesi hakkında kanun" bulunmaktadır. Kişilik haklarına saldırı, gerçeğe aykırı ve iftira niteliğindeki paylaşımları oluşturan ve yayanlar hakkında Cumhuriyet Savcılığı'na suç duyurusunda bulunulabileceği belirtilmiştir (Akar, 2016: 70).

\subsubsection{Etik ve Toplumsal Değerlere Uyum İhlalleri}

Her toplumda insanlar arasındaki ilişkileri düzenleyen etik değerler ve benimsenmiş olan ortak duygu ve düşünceler bulunmaktadır. Bu ortak duygu ve düşünceler toplumsal değerleri oluşturmaktadır. Toplumun bu ortak paydaları, dayanışma ve bütünleşmeyi sağlamaktadır. $\mathrm{Bu}$ değerlere uygun olmayan bir davranış sergilendiğinde toplum bu saygısızlı̆̆ı yapan kişi ya da kurumu hoş görmemektedir (Tuncer, 2014: 217).

Sosyal medyada hesapları bulunan kurumlar paylaşımlarında toplumsal değerleri gözeten içerikler paylaşmalıdır. Etik ve toplumsal değerlere saygılı olmayı bir sosyal medya politikası olarak uygulamaları gerekmektedir. Ayrıca sosyal medya yönetiminden sorumlu ekibe etik ve toplumsal değerlere uyum hakkında eğitimler verilerek karşılaşılabilecek risklerin önüne geçilmesi sağlanmalıdır (Çakır, 2015: 97).

$\mathrm{Bu}$ değerlere uymayan kurumlar sosyal medyada çok zor durumlara düşmekte, kurumların marka imajı zedelenebilmektedir. Çünkü toplum, sosyal medyada yapılabilecek diğer yanlışlıklara nazaran kendi değerlerine yapılan saygısızlığa çok daha sert tepkiler vermektedir (Çakır, 2015: 17).

\subsection{Sosyal Medya Risklerinin Kurumlara Verdiği Zararlar}

Kurumlar sosyal medya faaliyetlerini yürütürken çeşitli nedenlerden dolayı sosyal medya risklerine maruz kalabilmektedirler. Kurumların sosyal medyada yapacağı çok ufak bir hata bile sosyal medyanın hızı ve geniş etki alanı nedeniyle çok büyük sonuçlar 
doğurabilmektedir. Kurumlar için ciddi bir tehdit olan sosyal medya riskleri doğru bir şekilde yönetilmediği takdirde kurumlara önemli zararlar verebilmektedir. Satışların azalması, asılsız iftiralara maruz kalınması, verilerin çalınması gibi etkilerinin yanı sıra kurum geleceğinin tehlike altına sokabilecek sonuçlar da doğurabilmektedir. Aşağıdaki tabloda sosyal medya risklerinin yol açtı̆̆g zararlar gösterilmektedir.

Tablo 1. Risklerin Sonuçları
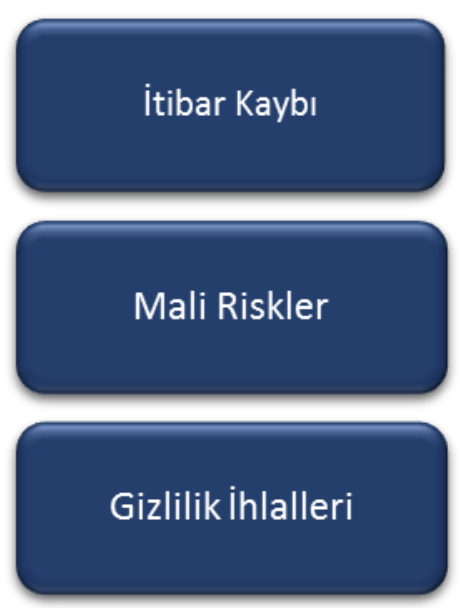

Hukuki Riskler

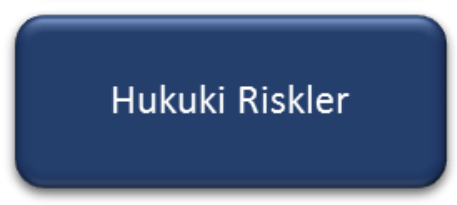

Etik ve Toplumsal

Değerlere Uyum

inlalleri
(1D Kurumsal imajın zarar görmesi

(11) Güven kaybı

(10) Kurum hakkında spekülasyonların ortaya atılması

(10) Kurum geleceğini tehdit etmesi

(10) Satışların azalması

(10) Müşteri kaybı

(10) Hisse senedi değerinin düşmesi

(1) Ürün ve hizmetlerin boykot edilmesi

(1) Kurum verilerinin çalınması

(1D Sistem altyapısının zararlı yazılımlara maruz kalması

(11) Sosyal medya hesaplarının hacklenmesi

(11) Hacklenen sosyal medya hesaplarının istismar edilmesi

(1) Kurum aleyhine açılan davalar

(10) Maddi cezalar

(10) Telif hakları cezaları

(10) Reklamların yasaklanması

(10) Küfür, hakaret ve taciz mesajları

(1) Protestolar, imza kampanyaları

(1) Kamuoyu nezdinde kurumun küçük düşürülmesi

(11) Asılsız iftiralar ve kara propagandalar

\section{4. İÇ DENETIMIN SOSYAL MEDYA RİSKLERİ KARŞISINDAKİ ROLÜ}

"İç denetim, bir kurumun faaliyetlerini geliştirmek ve onlara değer katmak amacını güden bağımsız ve tarafsız bir güvence ve danışmanlık faaliyetidir. İç denetim kurumun risk yönetimi, kontrol ve yönetişim süreçlerinin etkililiğini değerlendirmek ve geliştirmek amacına yönelik sistematik ve disiplinli yaklaşım getirerek kurum hedeflerinin gerçekleştirilmesine yardımc1 olur (Özbek, 2012: 3)."

İç denetimden beklenen faydalar zaman içerisinde değişikliğe uğramıştır. 1990’11 yıllarda iç denetimden beklenen kurumun varlıklarını korumak iken 2000'li yıllarda kuruma değer katmak olmuştur. Gelişen ve değişen iş dünyasına göre iç denetim de gelişim ve değişimini sürdürmüştür (Adiloğlu, 2011: 8).

Hem bireyler hem de kurumlar için hayatın önemli bir parçası haline gelmiş olan sosyal medya platformları hayatımızın odak noktası konumundadır ve gerek bireylerin gerekse kurumların sosyal medyadan uzak durması olanaksızdır. Özellikle kurumların sosyal 
medya hesabı bulunmasa bile sosyal medyayı kullanan kişilerce, kurum hakkında paylaşım ve yorum yapılabilmektedir (İnci, 2014: 38). Bu nedenle günümüzde artık birçok kurumun sosyal medya hesabı ve bu hesabı yöneten ekibi bulunmaktadır. Bu ekipte uzman kişiler istihdam edilmektedir. Ayrıca sosyal medya ajanslarından danışmanlık hizmeti de alarak sosyal medya platformlarını etkili bir şekilde kullanmayı amaçlamaktadırlar (Mestçi, 2013: 40). Sosyal medya doğru yönetildiğinde hedef kitle ile doğrudan etkileşim, güçlü bir marka imajı oluşturma, satışları arttırma gibi birçok fayda yaratabilirken, yanlış yönetilmesi durumunda ise birçok riski barındırmaktadır. Kurumların sosyal medyada birçok riske maruz kalabilecek olması, risklerin tespit edilmesinde, önlenmesinde, yönetilmesinde ve sürecinin etkinliğinin değerlendirilmesinde ve geliştirmesinde iç denetimi oldukça önemli bir konuma getirmektedir. İç denetim, sosyal medya konusundaki sorumluluklarını yerine getirerek sosyal medya faaliyetlerine yardımcı olmakta, sosyal medya risklerinin önlenmesi ve yönetilmesinde güvence sağlamaktadır (Mennie, 2015: 88).

İç denetim birimi bu amaçla sosyal medya süreçlerinin ve bu süreçlerin aşamalarının sağlıklı bir şekilde işleyip işlemediğinin değerlendirmesini yapabilmesi için süreçte sorgulanması gereken unsurları planlayıp denetimlerini gerçekleştirmektedir.

\subsection{Sosyal Medya Stratejisi ve Politikalarının Denetlenmesi}

İç denetimin sosyal medya biriminde yapacağı incelemelerin başında strateji ve politika denetimi gelmektedir. Sosyal medya kullanımının amaçlarına ulaşabilmesi için doğru bir strateji belirleyip daha sonrasında ise doğru politikalarla desteklenmelidir. İç denetim birimi bu doğrultuda

- $\quad$ Sosyal medya stratejisi ve

- $\quad$ Sosyal medya politikasının denetimini gerçekleştirmektedir.

Hedef: Sosyal medya stratejisi ve politikalarının kurumun genel hedef ve stratejilerine uygun bir şekilde belirlenip belirlenmediğinin ve düzenli bir şekilde uygulanıp uygulanmadığının tespit edilmesidir.

$\mathrm{Bu}$ amaca yönelik olarak incelenmesi gereken dokümanlar;

i. $\quad$ Kurumsal strateji, misyon ve vizyona ait dokümanlar

ii. $\quad$ Sosyal medya stratejisi ve planı

iii. Üst yönetim toplantı tutanakları

iv. Sosyal medya yönetim kılavuzu

Teorik temele dayanarak bir değerlendirme yapılabilmesi için sorgulanması gereken unsurlar ise şu şekilde planlanabilir.

\section{Sosyal Medya Stratejisi}

a. Sosyal medya stratejisi açık bir şekilde tanımlanmış mıdır? belirlenmiştir?

b. Sosyal medya stratejisi kurumun genel stratejisi ile aynı doğrultuda mı

c. Sosyal medya stratejisinin hazırlanmasından sorumlu kişiler kimlerdir?

d. Sosyal medya stratejisi hazırlanırken sosyal medya riskleri göz önünde bulundurulmuş mudur? 
e. Sosyal medya stratejisine uygun olan sosyal medya platformları belirlenmiş midir?

f. Stratejinin gerçekleşmesi için gerekli kaynaklar (reklam bütçesi, eğitimler) ayrılmış mıdır?

g. Kurumun sosyal medyada bulunma amacı ve hedefleri belirlenmiş midir?

h. Kurumun sosyal medyada ne derece aktif olacağ $\quad$ belirlenmiş midir?

\section{Sosyal Medya Politikası}

a. Sosyal medyada uyulması gereken ilkeler belirlenmiş midir? Bu ilkeler açık bir şekilde tanımlanmış mıdır?

b. Sosyal medya politikaları ile kurum ilkeleri arasında çelişki var mıdır?

c. Sosyal medya politikaları genel sosyal medya stratejisine uygun mudur?

d. Sosyal medyada nelerin yapılabilir, nelerin yapılamaz olduğunun sinırları belirlenmiş midir?

e. Kurumun hem çalışanlarına yönelik hem de hedef kitlesi olan müşterilerine yönelik iç ve dış sosyal medya politikaları mevcut mudur?

f. Sosyal medyada kurumla alakalı yapılan olumlu/olumsuz yorumlara karşı yaklaşım tarzı belirlenmiş midir?

g. Kurumun, çalışanlarından veya sosyal medya kullanıcılarından dolayı uğraması muhtemel zararlara ilişkin bir yaptırım politikası var mıdır?

Denetimlerde uygulanacak ek testler;

i. Mevcut durumun ilgililer tarafından bilindiğinin doğrulaması yapılmalıdır.

ii. Yönetim kurulu toplantı tutanakları incelenerek, stratejinin usulüne uygun bir şekilde onaylanıp onaylanmadığı denetlenmelidir.

\subsection{Sosyal Medya Operasyon Sürecinin Denetlenmesi}

Sosyal medya faaliyetlerinin operasyon süreci sosyal medya kullanıcılarıyla etkileşimin kurulduğu aşamadır. İletişimin sağlıklı bir şekilde kurulup sosyal medya faaliyetlerinin sürdürülmesi için bu sürecin doğru bir şekilde yürütülmesi gerekmektedir. İç denetim birimi bu doğrultuda

- $\quad$ Görev ve sorumluluk

- $\quad$ İçerik paylaşımı

- $\quad$ Takip ve izleme aşamalarının denetimini gerçekleştirmektedir.

Hedef: Sosyal medya operasyon sürecinin görev ve sorumluluk, içerik paylaşımı, takip ve izleme aşamalarının uygun bir şekilde yürütülüp yürütülmediğinin belirlemesidir.

$\mathrm{Bu}$ amaca yönelik olarak incelenmesi gereken dokümanlar;

i. Organizasyon şemaları ve görev tanımları

ii. Sosyal medya takibi ve izleme raporlar1

iii. Paylaşılan tüm sosyal medya içeriklerinin dökümü

Teorik temele dayanarak bir değerlendirme yapılabilmesi için sorgulanması gereken unsurlar ise şu şekilde planlanabilir. 


\section{Görev ve Sorumluluklar}

a. Sosyal medya ekibinde bulunan tüm personelin yetki ve sorumlulukları yazılı bir şekilde belirlenmiş midir?

b. Sosyal medya birimi doğru bir şekilde yapılandırılmış mıdır?

c. Belirlenen görev ve sorumluluklar çalışanlar tarafindan yerine getirilmekte midir?

d. Sosyal medya ekibi diğer departmanlarla uyumlu çalışabilmekte midir?

e. Sosyal medya ekibi görev ve sorumluluklar için yeterli yetkinliğe sahip midir?

\section{İçerik Paylaşımı}

midir?

a. Paylaşımların hangi ölçütlere uyması gerektiğini gösteren bir içerik planı var

b. Kurum tarafından paylaşılan içerikler taraflı, yanıltıcı ve siyasi yorumlar içermekte midir?

c. Paylaşılan içerikler sosyal medya politikası ve stratejisine uygun mudur?

d. Sosyal medyada paylaşılan içerik, görsel veya bilgilendirmeler paylaşılmadan önce denetimden geçirilmekte midir?

e. İçerikler toplumsal ahlak ve etik kurallarına uygun mudur?

f. İçerikler hukuk kurallarını ihlal etmekte midir?

g. Tüm ulusu derinden etkileyen üzücü olaylar yaşandığında rutin akışta değişiklik yapılmakta mıdır?

h. Paylaşılan içerikler yaratıcı, ilgi çekici ve güncel midir?

\section{Takip ve İzleme} edilmekte midir?

a. Kurum hakkında sosyal medyada yapılan yorum ve paylaşımlar takip

b. Paylaşılan içeriklere yapılan yorumlar incelenmekte midir?

c. Kurum paylaşımlarının etkileşimi ya da kurum hakkında yapılan paylaşımların istatistiki verileri takip ve analiz edilmekte midir?

d. Kurumun ürün ya da hizmeti hakkında sosyal medyada yapılan eleştiriler ilgili birimlere bildirilmekte midir?

e. Sosyal medya ile alakalı değişen ve gelişen trendler takip edilmekte midir?

f. Sosyal medya ekibi kurumun hedef kitlesi konumunda bulunan kullanıcıların, kurumdan beklentileri hakkında bilgi sahibi midir?

g. Sosyal ağlar analiz edilerek kullanıcıların tutum ve davranışları, beklentileri, demografik özellikleri gibi bilgileri toplanmış mıdır?

h. Sosyal medyadaki takip edilme ve beğenilme sayıları kurumun rakipleriyle karşılaştırılmakta mıdır?

Denetimlerde uygulanacak ek testler;

i. $\quad$ Ekibin performansı izlenerek mevcut durumla hedefler karşılaştırılmalıdır.

ii. Ekibin eğitimi ve tecrübeleri incelenerek eksik olan yönler tespit edilmelidir.

\subsection{Sosyal Medya Hesaplarının Güvenlik Risklerine Karşı Denetlenmesi}

Sosyal medya hesaplarının güvenliğinin ve gizliliğinin sağlanması için kurumların bazı altyapısal ve sistemsel önlemler almaları gerekmektedir. Sosyal medya hesaplarının korsan saldırılardan etkilenmemesi için iç denetim birimi tarafindan 
- $\quad$ Sosyal medya hesaplarının güvenliğinin ve

- $\quad$ Sistem güvenliğinin denetimi gerçekleştirilmektedir.

Hedef: Kurum altyapısının ve sosyal medya hesabının yaşanabilecek güvenlik risklerine karşı güvende olup olmadığının belirlenmesidir.

$\mathrm{Bu}$ amaca yönelik olarak incelenmesi gereken dokümanlar;

i. Güvenlik protokolleri

ii. Sosyal medya hesaplarına giriş yapan IP numaralarının kaydı

iii. Sosyal medya ekibinin özgeçmişleri

Teorik temele dayanarak bir değerlendirme yapılabilmesi için sorgulanması gereken unsurlar ise şu şekilde planlanabilir.

\section{Sosyal Medya Hesap Güvenliği}

a. $\quad$ Sosyal medya hesaplarının güvenliğiyle alakalı yazılı bir güvenlik prosedürü mevcut mudur?

b. Sosyal medya hesaplarına giriş yetkisi kim veya kimlerde bulunmaktadır?

c. Sosyal medya hesaplarının şifreleri kim veya kimler tarafindan bilinmektedir?

d. Sosyal medya hesaplarının şifreleri yeterli güvenlikte midir? Şifrede harf, rakam ve özel sembol bulunan 3'lü kombinasyon kullanılmakta mıdır? değiştirilmektedir?

e. Sosyal medya hesaplarının şifreleri kaç aylık periyotlarda bir

f. Sosyal medya hesaplarına erişim sadece kurum alt yapısına bağlı bulunan bilgisayarlardan $\mathrm{m}$ yapılmaktadır?

g. Hesap güvenliğiyle alakalı bir güvenlik ihlali olduğunda veya hesap ele geçirildiğinde uygulanacak eylem planı hazır mıdır?

h. $\quad$ Sosyal medya ekibine güvenlik ve gizlilikle alakalı gerekli bilgilendirmeler yapılmış mıdır? Eğitimler verilmiş midir?

\section{Sistem Güvenliği}

a. Kurumun altyapısı sosyal medya hesaplarının güvenliğinin sağlanması için yeterli seviyede midir?

b. Kurumsal sosyal medya hesaplarına giriş yapan cihazlardan hangi işlemlerin yapıldığını kayıt edebilen ve raporlayabilen bir sistem bulunmakta mıdır?

c. Sistem güvenliğini sağlamak için kodmatik veya doğrulama kodu girilerek erişime imkan tanıyan ek güvenlik önlemleri bulunmakta mıdır?

d. Teknolojik gelişmelerle giderek gelişen korsan yazılımlara karşı altyapıya gerekli güncellemeler ve yenilemeler yapılmakta mıdır? yapılmakta midir?

e. Sistem ve altyapı güvenliği gibi konularda IT birimiyle koordineli bir çalışma Denetimlerde uygulanacak ek testler;

i. Güvenlik riskleriyle alakalı yapılmış olan bilgilendirmeler ve eğitimler denetlenmelidir.

ii. Altyapı hizmeti alınan kurumlarla yapılan sözleşmeler incelenmelidir. 


\subsection{Sosyal Medyanın Kurumun İtibarına ve Gelirine Etkisinin Denetimi}

Sosyal medyanın kurumun itibarına ve gelirine yönelik olumlu veya olumsuz etkileri olabilmektedir. İç denetim birimi; sosyal medya satış rakamlarını, sosyal medya ölçümlerini ve bazı sosyal medya raporlarını inceleyerek sosyal medyanın

- $\quad$ Kurumun itibarına ve

- $\quad$ Gelirine yönelik etkisinin denetimini gerçekleştirmektedir.

Hedef: Sosyal medyanın, kurumun itibarına ve gelirine yönelik olumlu veya olumsuz etkisinin ortaya çıkarılmasıdır.

$\mathrm{Bu}$ amaca yönelik olarak incelenmesi gereken dokümanlar;

i. $\quad$ Sosyal medya aracılığıyla gerçekleşen satış rakamları

ii. $\quad$ Sosyal medya ölçümleme raporları

iii. Risk değerlendirme raporları

Teorik temele dayanarak bir değerlendirme yapılabilmesi için sorgulanması gereken unsurlar ise şu şekilde planlanabilir.

\section{Kurum İtibarı} edilmekte midir?

a. Kurumsal itibar kaybına neden olabilecek sosyal medya riskleri analiz midir?

b. Kurumsal itibarı korumak ve artırmak için sosyal medyada çalışma yapılmakta

c. Kurumsal itibar ile alakalı sosyal medya analizi, takibi ve raporlaması yapilmakta midır?

d. Kurumun sosyal medyadaki itibarını etkileyebilecek olumsuz durumlar için bir aksiyon planı var midır? midir?

e. Kurum itibarı için sosyal medyada sosyal sorumluluk kampanyaları yapılmakta

\section{Kurum Gelirleri}

a. Sosyal medya aracılığıyla gerçekleşen satış rakamları incelenmekte midir?

b. Sosyal medyada paylaşılan haber, kampanya ve ürün tanıtımlarına yapılan yorum, beğeni ve paylaşımların sayıları analiz edilmekte midir?

c. Sosyal medyanın marka bilinirliği yaratmada katkısı var mıdır? midir?

d. Kurumun sosyal medyada yaşadığı krizlerin gelire olan etkileri belirlenmiş

e. Geçmişte başka kurumların yapmış olduğu başarılı sosyal medya kampanyaları takip ve analiz edilmekte midir?

f. Ürün ve hizmetlerin satışı için yapılan reklam ve pazarlama faaliyetleri sosyal medya ile desteklenmekte midir?

Denetimlerde uygulanacak ek testler;

i. Sosyal medya platformlarında kurumun adı aratılarak itibar ve imajla alakalı incelemeler yapılmalıdır.

ii. Kurumsal itibar için sosyal medyada yapılan anket ve ölçümler incelenmelidir. 


\subsection{Risk ve Kriz Sürecinin Denetimi}

Sosyal medyada her kurum risk ve krizle karşılaşabilmektedir. $\mathrm{Bu}$ sürecin yanlış yönetilmesinin kuruma önemli zararları olabileceğinden doğru bir kurguyla tasarlanıp, sağlıklı bir şekilde yürütülmesi gerekmektedir. İç denetim birimi bu doğrultuda

Muhtemel risk ve kriz süreci öncesinde ve

Muhtemel risk ve kriz süreci sırasında bulunması gereken unsurların denetimini gerçekleştirmektedir.

Hedef: Sosyal medyada yaşanabilecek risk ve kriz sürecinin doğru bir şekilde hazırlanıp hazırlanmadığının tespit edilmesidir.

$\mathrm{Bu}$ amaca yönelik olarak incelenmesi gereken dokümanlar;

i. $\quad$ Risk ve kriz süreci aksiyon planı

ii. Risk analiz raporu

iii. Kriz iletişimi planı

Teorik temele dayanarak bir değerlendirme yapılabilmesi için sorgulanması gereken unsurlar ise şu şekilde planlanabilir.

\section{Muhtemel Risk ve Kriz Süreci Öncesi}

a. $\quad$ Risk ve kriz süreci ile alakalı yazılı bir aksiyon planı mevcut mudur?

b. Sosyal medyada karşılaşılabilecek riskler belirlenip kategorize edilmiş midir?

c. Sosyal medya riskleri için risk matrisi hazırlanmış mıdır?

d. Takipçilerle doğru ve seviyeli bir iletişim gerçekleşmekte midir?

e. Geçmişte yaşanmış kriz iletişimlerinin analizi yapılmış mıdır?

f. Sosyal medya strateji ve politikalarına uyumsuz bir uygulama var mıdır?

g. Hukuk birimiyle koordineli bir çalışma yürütülmekte midir?

\section{Muhtemel Risk ve Kriz Süreci Sırasında}

a. Krize neden olan olaylar tespit edilmiş midir?

midir?

b. Krize neden olan olayların kim veya kimler tarafından yayıldı̆̆ midir?

c. Krizi yayanlar arasında kanaat önderleri (gazeteci, yazar, ünlü bir kişi) var

d. Krize zamanında müdahale edilmiş midir?

e. Kriz iletişiminde kullanılacak strateji ve taktikler hazırlanmış mıdır?

midir?

f. Yaşanan kriz sürecinin kurumun hangi varlıklarını tehdit ettiği belirlenmiş

Denetimlerde uygulanacak ek testler;

i. Kriz sürecindeki karar ve onay mekanizmalarının denetimi yapılmalıdır.

ii. Kriz süreciyle alakalı davaların gidişatı veya sonuçlarıyla alakalı incelemeler gerçekleştirilmelidir. 


\section{SONUÇ}

İnternet teknolojilerindeki gelişmeler sonucu ortaya çıkan ve her geçen gün yeni bir işlevi keşfedilen sosyal medya, hayatımızın önemli bir parçası haline gelerek yaşantımıza doğrudan etki etmektedir. Sosyal medyanın etki alanı o kadar geniştir ki bu etkiler sadece kişilerle sınırlı kalmayarak kurumları da etkilemektedir.

Kurumlar için sosyal medyanın; ürün ve hizmetlerini pazarlamak, güçlü bir marka algısı yaratmak, kurumsal itibarını artırmak, müşteriyle doğrudan iletişim kurmak ve aralarındaki ilişki bağını kuvvetlendirmek gibi pek çok önemli işlevi vardır. $\mathrm{Bu}$ önemli katkılarından dolayı kurumların sosyal medyaya verdikleri önem her geçen gün artmaktadır. Kurumlar sosyal medyanın sunduğu firsatlardan daha çok yararlanabilmek için bu alana daha fazla yatırım yapmaktadır.

Kurumlar için yeni bir iletişim ortamı sağlayan sosyal medya, kurumlara sayısız katma değer sağlamaktadır. Ancak yanlış yönetildiğinde ise sosyal medya kurumlara önemli zararlar verebilecek riskleri doğurabilmektedir. Bu riskler; itibar kaybı, mali kayıplar, etik ve toplumsal değerlere uyum ihlalleri, gizlilik ihlalleri ve hukuki risklerdir. Sosyal medyanın etki alanının çok geniş olması nedeniyle yaşanabilecek riskler kurumlar için telafi edilmesi çok zor sonuçlar ortaya çıkarabilmektedir.

Kurumların yıllarca sürdürdükleri çalışmalar sonucu kazandıkları itibarları, sosyal medyada yapılan yanlış bir paylaşımla ciddi zararlar görebilmektedir. Kurumların ürünlerinin veya hizmetlerinin boykot edilmesine kadar varabilen sonuçları doğurabilmektedir. Kurumlar bu süreçte önemli mali kayıplara uğrayabilmekte ve kurumların imajı zedelenebilmektedir. Ayrıca bu hatalar sonucu kurumlar çeşitli davalarla karşı karşıya kalabilmektedir.

Son dönemlerdeki gelişen yapısıyla birlikte kuruma değer katan ve süreçlerin daha iyi işlemesini sağlamak gibi fonksiyonları da bulunan iç denetim sadece mali süreçlerle ilgilenmemektedir. Kurumlarda yaşanabilecek risklerin tespit edilmesi ve önlenmesinde önemli sorumlulukları bulunmaktadır. Risk yönetiminin başarılı bir şekilde uygulanmasını sağlayarak faaliyetlerin daha sağlıklı işlemesini ve yaşanabilecek risklerin önlenmesini amaçlamaktadır.

Çalışmanın son kısmında sosyal medya süreçlerinin ve bu süreçlerin aşamalarının denetlenmesine yer verilmiştir. Denetimde sosyal medya süreçlerinde buluması gereken unsurlar sorgulanmıştır. $\mathrm{Bu}$ sorgulamalar neticesinde iç denetimin, sosyal medya faaliyetlerinin risklere maruz kalmadan sağlıklı bir şekilde yürütülmesi için üstlendiği soumluluklar belirtilerek sosyal medya risklerinin yönetilmesindeki önemli rolü ortaya konulmuştur.

\section{KAYNAKLAR}

Adiloğlu, Burcu. (2011), “İç Denetim Süreci ve Kontrol Prosedürleri”, 1.Bask1, Türkmen Kitabevi, İstanbul.

Akar, Erkan. (2016), “İşletmeler İçin Sosyal Medyanın Yasal Riskleri”, 1.Baskı, Adalet Yayınevi, Ankara. 
Cross, Michael. (2014), "Social Media Security Leveraging Social Networking While Mitigating Risk", 1st Edition, Elsevier Publishers, USA.

Çakır, H. Özdemir. (2016), “Sosyal Medyada Kurumsal İtibar Yönetimi”, 1.Baskı, Kriter Yayınevi, İstanbul.

Dağıtmaç, Murat. (2015), “Sosyal Medya Bizi Neden Kullanır”, Metamorfoz Yayıncılık, İstanbul.

İnci, Tuba. (2014), “İç Denetimin İtibarının Yönetimi”, İç Denetim Dergisi, Sayı 38, ss. 35-39.

Karahasan, Sait. (2017), “Sosyal Medya ve Web Güvenliği”, KuveytTürk Katılım ve Finans Dergisi, Mayıs. ss. 15-19.

Kazancı Şerife\&Başgöze Pınar. (2015), “Sosyal Medya Algısının, Markanın Kredibilitesinin ve Marka Prestijinin Satın Alma Eğilimi Üzerine Etkileri”, Ankara Üniversitesi SBF Dergisi, Cilt 70, ss. 430-455.

Mavnacığlu, Korhan. (2015), “Kurumsal İletişimde Sosyal Medya Yönetimi”, 1.Baskı, Beta Yayınları, İstanbul.

Mestçi, Aytaç. (2013), “Bir Sosyal Medya Danışmanının Anıları”, 1.Baskı, Pusula Yayıncılık, İstanbul.

Mennie, Phil. (2015), “Social Media Risk and Governance Managing Enterprise Risk”,1st Edition, Kogan Page Publishers, United Kingdom.

Oxley, Alan. (2013), “Security Risks In Social Media Technologies”, 1st Edition, Chandos Publishing, United Kingdom.

Özbek, Çetin. (2012), “İç Denetim Kurumsal Yönetim Risk Yönetimi İç Kontrol (Cilt No:1)”, 1.Baskı, TİDE Yayınları, İstanbul.

Sezgin, Cüneyt. (2014), “İç Denetimin İtibarının Yönetimi”, İç Denetim Dergisi, Sayı:38, ss.40-43.

Scott, R. Peter\&Jacka, J. Mike. (2013), “Sosyal Medya: Kurumsal Yönetim ve Risk Rehberi”, 1.Baskı, TIDDE Yayınları, İstanbul.

Tuncer, Emre. (2014), “Sosyal Medya İmparatorluğu Patron”, 1.Bask1, Akis Yayınlar1, İstanbul.

Vardarlier, Pelin. (2016), “Sosyal Medya Stratejisi”, 1.Baskı, Nobel Yayınc1lık, Ankara.

www.koc.com.tr, 04.05.2017.

www.pwc.com.tr, 24.11.2017. 